\title{
Seat Belt Use Among Adult Workers — 21 States, 2013
}

\author{
Winifred L. Boal, MPH${ }^{1}$; Jia Li, MS ${ }^{1}$; Rosa L. Rodriguez-Acosta, $\mathrm{PhD}^{2}$
}

Roadway incidents involving motorized vehicles accounted for $24 \%$ of fatal occupational injuries in the United States during 2013 and were the leading cause of fatal injuries among workers. ${ }^{*}$ In 2013, workers' compensation costs for serious, nonfatal injuries among work-related roadway incidents involving motorized land vehicles were estimated at $\$ 2.96$ billion. ${ }^{\dagger}$ Seat belt use is a proven method to reduce injuries to motor vehicle occupants (I). Use of lap/shoulder seat belts reduces the risk for fatal injuries to front seat occupants of cars by $45 \%$ and the risk to light truck occupants by $60 \% .{ }^{\$}$ To characterize seat belt use among adult workers by occupational group, $\mathrm{CDC}$ analyzed data from the 2013 Behavioral Risk Factor Surveillance System (BRFSS) and found that not always using a seat belt was significantly associated with occupational group after controlling for factors known to influence seat belt use. Occupational groups with the highest prevalences of not always using a seat belt included construction and extraction; farming, fishing, and forestry; and installation, maintenance, and repair. To increase seat belt use among persons currently employed, states can enact and enforce primary seat belt laws, employers can set and enforce safety policies requiring seat belt use by all vehicle occupants, and seat belt safety advocates can target interventions to workers in occupational groups with lower reported seat belt use.

BRFSS is an annual, state-based, random-digit-dialed landline and cell phone survey of noninstitutionalized adults aged $\geq 18$ years residing in the United States. ${ }^{9}$ In 2013, all states asked survey participants about seat belt use.** Industry and occupation were first available on the BRFSS survey in 2013,

\footnotetext{
* http://www.bls.gov/iif/oshwc/cfoi/cfoi_revised13.pdf.

$\dagger$ https://www.libertymutualgroup.com/about-lm/research-institute/ communications/workplace-safety-index.

$\$$ http://www-nrd.nhtsa.dot.gov/Pubs/812153.pdf.

http://www.cdc.gov/brfss/.

** Seat belt use was elicited by the question, "How often do you use seat belts when you drive or ride in a car? Would you say—always, nearly always, sometimes, seldom, never?"
}

and 21 states asked currently employed respondents about their industry and occupation. ${ }^{\dagger \dagger}$ This report describes selfreported seat belt use by occupational group among workers in those 21 states who were employed for wages or self-employed at the time of the interview. All responses to the question about frequency of seat belt use except "always" (i.e., "nearly always," "sometimes," "seldom," and "never") were combined and categorized as "not always." Participants' responses were coded to 2002 U.S. Census Bureau occupation numeric codes. Census occupation codes were then grouped for analysis into 2000 Standard Occupational Classification (SOC) System major groups. Records with missing occupation codes or that were not able to be coded because of insufficient information were excluded, as were records where the seat belt responses

\footnotetext{
$\mp \dagger$ Occupation was elicited by the question, "What kind of work do you do (for example, registered nurse, janitor, cashier, auto mechanic)?"
}
INSIDE
598 Disparities in Adolescents' Residence in Neighborhoods Supportive of Physical Activity - United States, 2011-2012
602 Male Attendance at Title X Family Planning Clinics — United States, 2003-2014
606 Notes from the Field: Typhoid Fever Outbreak Associated with an Asymptomatic Carrier at a Restaurant - Weld County, Colorado, 2015
608 Notes from the Field: Strongyloidiasis at a Long- Term-Care Facility for the Developmentally Disabled — Arizona, 2015
610 Announcement
611 QuickStats
Continuing Education examination available at http://www.cdc.gov/mmwr/cme/conted_info.html\#weekly.

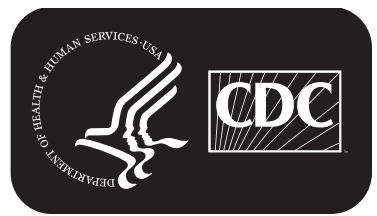

U.S. Department of Health and Human Services Centers for Disease Control and Prevention 
were blank, "don't know/not sure," "never drive or ride in a car," or "refused." Because BRFSS data are not representative of active duty service members, the 263 respondents who worked in the armed forces also were excluded.

Results were stratified by type of seat belt law in the state of residence because type of law is known to be associated with seat belt use $(1,2)$. Fourteen of the 21 states had primary seat belt laws in 2013; in these states, a driver can be stopped and ticketed solely for not using a seat belt. Six states had secondary seat belt laws; in these states, a driver can be ticketed for not using a seat belt only if stopped for another offense. New Hampshire had no seat belt law covering adults ${ }^{\S \S}$ and was grouped with the secondary law states.

Data were weighted and analyzed to account for the complex BRFSS multistage sampling design. The prevalence of not always using a seat belt was estimated by occupational group and sociodemographic characteristics. Adjusted prevalences, stratified by type of seat belt law, were estimated with logistic regression controlling for the potential confounders of age, sex, race/ethnicity, education, marital status, body mass index, and county urbanization. All statistically significant interaction terms between occupational group and confounders, including the interaction between occupational group and type of seat belt law, were included in the model. County of residence was classified as metropolitan (codes 1-3), urban (4-7), or rural

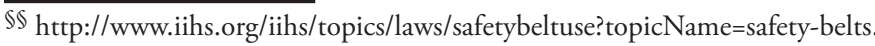

(8-9), based on the U.S. Department of Agriculture's 2013 Rural-Urban Continuum Codes. 99

Among the 21 states, the overall survey response rates ranged from $31.1 \%$ to $59.2 \%$. $^{* * *}$ Data from 84,593 respondents were included in the analysis, including 54,187 (64\%) who lived in states with primary seat belt laws and 30,406 (36\%) who lived in states with secondary seat belt laws. The prevalence of not always using a seat belt varied by age, sex, race/ethnicity, education, marital status, body mass index, and county urbanization, and for each characteristic, was higher in states with secondary seat belt laws (Table 1).

For all occupational groups combined, the crude prevalence of not always using a seat belt was $10.4 \%$ in states with primary seat belt laws and $23.6 \%$ in states with secondary seat belt laws (Table 2). For every occupational group, the prevalence was higher in states with secondary seat belt laws. Crude prevalences ranged from $5.4 \%$ (business and financial operations) to $18.0 \%$ (construction and extraction) in the states with primary seat belt laws and from $8.1 \%$ (life, physical, and social science) to $55.5 \%$ (farming, fishing, and forestry) in states with secondary seat belt laws. Among workers in the transportation and material moving group, which includes several occupations that involve frequent driving, $12.4 \%$ and $33.7 \%$ in states with primary and secondary seat belt laws, respectively, did not always use a seat belt.

99 http://www.ers.usda.gov/data-products/rural-urban-continuum-codes.aspx. *** http://www.cdc.gov/brfss/annual_data/2013/pdf/2013_dqr.pdf.

The MMWR series of publications is published by the Center for Surveillance, Epidemiology, and Laboratory Services, Centers for Disease Control and Prevention (CDC), U.S. Department of Health and Human Services, Atlanta, GA 30329-4027.

Suggested citation: [Author names; first three, then et al., if more than six.] [Report title]. MMWR Morb Mortal Wkly Rep 2016;65:[inclusive page numbers].

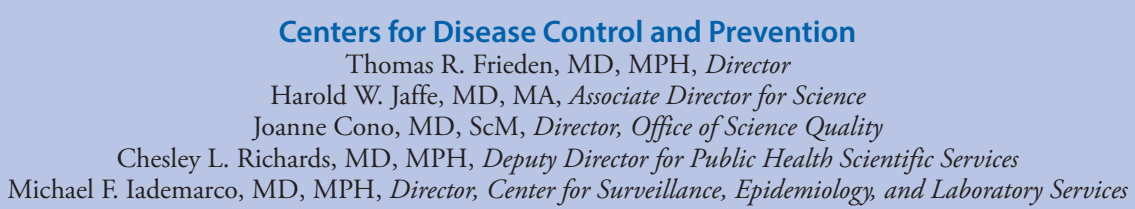

MMWR Editorial and Production Staff (Weekly)

Sonja A. Rasmussen, MD, MS, Editor-in-Chief

Charlotte K. Kent, PhD, MPH, Executive Editor Jacqueline Gindler, MD, Editor

Teresa F. Rutledge, Managing Editor

Douglas W. Weatherwax, Lead Technical Writer-Editor

Soumya Dunworth, PhD, Teresa M. Hood, MS, Technical Writer-Editors

Timothy F. Jones, MD, Chairman

Matthew L. Boulton, MD, MPH

Virginia A. Caine, MD

Katherine Lyon Daniel, $\mathrm{PhD}$

Jonathan E. Fielding, MD, MPH, MBA

David W. Fleming, MD

Martha F. Boyd, Lead Visual Information Specialist

Maureen A. Leahy, Julia C. Martinroe,

Stephen R. Spriggs, Moua Yang, Tong Yang, Visual Information Specialists

Quang M. Doan, MBA, Phyllis H. King, Terraye M. Starr, Information Technology Specialists

MMWR Editorial Board

William E. Halperin, MD, DrPH, MPH

King K. Holmes, MD, PhD

Robin Ikeda, MD, MPH

Rima F. Khabbaz, MD

Phyllis Meadows, PhD, MSN, RN

Jewel Mullen, MD, MPH, MPA
Jeff Niederdeppe, PhD

Patricia Quinlisk, MD, MPH

Patrick L. Remington, MD, MPH

Carlos Roig, MS, MA

William L. Roper, MD, MPH

William Schaffner, MD 
Morbidity and Mortality Weekly Report

TABLE 1. Prevalence* of not always using a seat belt among currently employed workers, by selected characteristics and state seat belt law status - Behavioral Risk Factor Surveillance System, 21 states, 2013

\begin{tabular}{|c|c|c|c|c|}
\hline \multirow[b]{2}{*}{ Characteristic } & \multicolumn{2}{|c|}{ States with primary seat belt laws ${ }^{\dagger}$} & \multicolumn{2}{|c|}{ States with secondary seat belt laws ${ }^{\S}$} \\
\hline & No. in sample & $\begin{array}{c}\text { Not always using seat belt } \\
\%(95 \% \mathrm{Cl})\end{array}$ & No. in sample & $\begin{array}{c}\text { Not always using seat belt } \\
\%(95 \% \mathrm{Cl})\end{array}$ \\
\hline \multicolumn{5}{|l|}{ Age group (yrs) } \\
\hline $18-24$ & 2,753 & $19.9(16.9-22.8)$ & 1,671 & $33.3(30.0-36.6)$ \\
\hline $25-34$ & 7,232 & $13.1(11.7-14.4)$ & 4,353 & $27.9(25.8-30.0)$ \\
\hline $35-44$ & 10,010 & $9.2(8.2-10.2)$ & 5,579 & $21.1(19.4-22.9)$ \\
\hline $45-54$ & 14,304 & $8.4(7.4-9.3)$ & 7,590 & $21.4(20.0-22.8)$ \\
\hline $55-64$ & 14,346 & $7.5(6.7-8.3)$ & 8,037 & $19.6(18.2-21.1)$ \\
\hline$\geq 65$ & 5,542 & $6.8(5.5-8.1)$ & 3,176 & $21.3(18.8-23.8)$ \\
\hline \multicolumn{5}{|l|}{ Sex } \\
\hline Men & 24,770 & $13.3(12.4-14.1)$ & 14,622 & $30.1(28.9-31.4)$ \\
\hline Women & 29,417 & $7.1(6.4-7.7)$ & 15,784 & $16.1(15.1-17.0)$ \\
\hline \multicolumn{5}{|l|}{ Race/Ethnicity } \\
\hline White, non-Hispanic & 41,022 & $10.8(10.2-11.4)$ & 27,048 & $24.2(23.3-25.0)$ \\
\hline Black, non-Hispanic & 4,666 & $13.8(11.3-16.2)$ & 455 & $22.5(15.7-29.4)$ \\
\hline Other, non-Hispanic & 2,962 & $8.1(5.7-10.4)$ & 1,305 & $20.4(16.7-24.1)$ \\
\hline Hispanic & 4,778 & $8.3(6.9-9.6)$ & 1,300 & $19.1(15.9-22.2)$ \\
\hline \multicolumn{5}{|l|}{ Education } \\
\hline Less than high school & 2,534 & $11.2(9.0-13.5)$ & 1,063 & $33.5(28.8-38.2)$ \\
\hline High school graduate & 12,356 & $13.2(12.1-14.3)$ & 7,406 & $31.9(30.0-33.8)$ \\
\hline Some college or technical school & 15,034 & $11.4(10.3-12.4)$ & 8,972 & $25.8(24.4-27.3)$ \\
\hline College graduate or more & 24,192 & $7.2(6.5-7.9)$ & 12,923 & $14.3(13.4-15.2)$ \\
\hline \multicolumn{5}{|l|}{ Marital status } \\
\hline Married & 31,262 & $8.4(7.7-9.0)$ & 19,086 & $20.3(19.5-21.2)$ \\
\hline Divorced, widowed, or separated & 11,585 & $9.6(8.5-10.6)$ & 5,667 & $24.6(22.5-26.7)$ \\
\hline Never married or a member of an unmarried couple & 11,089 & $14.9(13.6-16.2)$ & 5,538 & $30.6(28.6-32.7)$ \\
\hline \multicolumn{5}{|l|}{ Body mass index } \\
\hline Underweight or normal & 17,679 & $9.8(8.8-10.9)$ & 10,070 & $19.6(18.3-20.9)$ \\
\hline Overweight & 19,256 & $10.2(9.3-11.0)$ & 10,963 & $24.4(23.0-25.8)$ \\
\hline Obese & 15,029 & $11.7(10.7-12.6)$ & 8,041 & $29.8(28.1-31.6)$ \\
\hline \multicolumn{5}{|l|}{ Metropolitan/Urban/Rural county of residence } \\
\hline Metropolitan & 41,406 & $9.8(9.2-10.4)$ & 16,912 & $20.2(19.2-21.2)$ \\
\hline Urban & 11,096 & $15.0(13.6-16.4)$ & 10,166 & $33.7(32.3-35.1)$ \\
\hline Rural & 1,685 & $20.0(16.4-23.6)$ & 3,328 & $46.8(44.5-49.2)$ \\
\hline
\end{tabular}

Abbreviation: $\mathrm{Cl}=$ confidence interval.

* Weighted estimates.

† California, Florida, Illinois, Louisiana, Maryland, Michigan, Minnesota, Mississippi, New Jersey, New Mexico, New York, Oregon, Washington, and Wisconsin ( $\mathrm{n}=54,187$, $64 \%$ of respondents).

$\S$ Massachusetts, Montana, Nebraska, New Hampshire (no seat belt law), North Dakota, Utah, and Wyoming ( $\mathrm{n}=30,406,36 \%$ of respondents).

Among all occupational groups, the adjusted prevalence of not always using a seat belt was higher in states with secondary seat belt laws. The highest adjusted prevalences in states with primary seat belt laws were observed in the construction and extraction (14.1\%); legal (14.0\%); installation, maintenance, and repair (12.8\%); protective service (12.7\%); and farming, fishing, and forestry (12.7\%) occupational groups. In states with secondary seat belt laws, the highest adjusted prevalences were in the farming, fishing, and forestry $(38.1 \%)$; construction and extraction $(32.1 \%)$; installation, maintenance, and repair (27.0\%); building and grounds cleaning and maintenance (25.9\%); and protective service (25.4\%) occupational groups. Percentage-point differences between adjusted prevalences of states with primary and secondary seat belt laws ranged from a low of 2.0 (life, physical, and, social science) to a high of 25.5 (farming, fishing, and forestry) (Table 2).

\section{Discussion}

This analysis provides, for the first time, seat belt use estimates among a wide variety of occupational groups in 21 U.S. states. It indicates that self-reported seat belt use among adult workers in those states varies by occupation and that this variation persists after adjustment for factors known to be associated with seat belt use (age, sex, race/ethnicity, education, marital status, body mass index, county urbanization, and state seat belt law type). Overall and by occupational group, in 2013, seat belt use among employed adults was lower in states that did not have primary seat belt laws.

Limited data are available on work-related seat belt use. A CDC study found that approximately $14 \%$ of long-haul truck drivers did not use a seat belt on every trip and that never using a seat belt at work was associated with living in a state that did not have a primary seat belt law (3). 
TABLE 2. Prevalence* of not always using a seat belt among currently employed workers, by occupational group ${ }^{\dagger}$ and state seat belt law status, ranked from lowest to highest crude prevalence among states with primary seat belt laws - Behavioral Risk Factor Surveillance System, 21 states, 2013

\begin{tabular}{|c|c|c|c|c|c|c|c|}
\hline \multirow[b]{2}{*}{ Occupational group } & \multicolumn{3}{|c|}{ States with primary seat belt laws ${ }^{\S}$} & \multicolumn{3}{|c|}{ States with secondary seat belt laws? } & \multirow{2}{*}{$\begin{array}{l}\text { Percentage-point } \\
\text { difference in } \\
\text { adjusted \% } \\
\text { between primary } \\
\text { and secondary } \\
\text { law states }\end{array}$} \\
\hline & $\begin{array}{l}\text { No. in } \\
\text { sample }\end{array}$ & $\begin{array}{l}\text { Not always using } \\
\text { seat belt, crude } \\
\%(95 \% \mathrm{Cl})\end{array}$ & $\begin{array}{c}\text { Not always using } \\
\text { seat belt, adjusted** } \\
\%(95 \% \mathrm{Cl})\end{array}$ & $\begin{array}{l}\text { No. in } \\
\text { sample }\end{array}$ & $\begin{array}{c}\text { Not always using } \\
\text { seat belt, crude } \\
\%(95 \% \mathrm{Cl})\end{array}$ & $\begin{array}{c}\text { Not always using } \\
\text { seat belt, adjusted** } \\
\%(95 \% \mathrm{Cl})\end{array}$ & \\
\hline Business and financial operations & 2,572 & $5.4(4.0-6.7)$ & $7.0(5.4-9.0)$ & 1,273 & $14.1(11.4-16.9)$ & $16.9(13.9-20.4)$ & -9.9 \\
\hline Life, physical, and social science & 1,014 & $6.2(3.5-8.9)$ & $8.1(5.3-12.4)$ & 519 & $8.1(5.5-10.7)$ & $10.1(7.4-13.8)$ & -2.0 \\
\hline Architecture and engineering & 1,481 & $6.3(4.3-8.4)$ & $6.6(4.7-9.1)$ & 797 & $15.7(12.0-19.3)$ & $14.9(11.6-18.9)$ & -8.3 \\
\hline Health care practitioners and technical & 4,658 & $6.7(4.8-8.6)$ & $9.1(6.8-12.1)$ & 2,530 & $15.1(12.6-17.5)$ & $19.2(16.5-22.3)$ & -10.1 \\
\hline Education, training, and library & 4,549 & $6.9(5.1-8.7)$ & $10.2(7.8-13.1)$ & 2,648 & $11.5(9.7-13.4)$ & $15.0(12.6-17.8)$ & -4.8 \\
\hline Computer and mathematical & 1,639 & $7.4(5.0-9.9)$ & $7.7(5.5-10.7)$ & 839 & $14.3(10.3-18.4)$ & $14.4(10.8-18.8)$ & -6.6 \\
\hline Office and administrative support & 6,561 & $8.1(6.9-9.4)$ & $9.5(8.0-11.2)$ & 3,692 & $17.7(15.8-19.7)$ & $18.4(16.2-20.7)$ & -8.9 \\
\hline Healthcare support & 1,353 & $9.2(6.2-12.2)$ & $9.8(7.0-13.6)$ & 733 & $21.1(16.6-25.6)$ & $20.6(16.3-25.7)$ & -10.8 \\
\hline Community and social services & 1,342 & $9.4(6.1-12.7)$ & $11.7(8.1-16.7)$ & 658 & $16.1(11.8-20.4)$ & $19.9(15.5-25.3)$ & -8.2 \\
\hline Personal care and service & 1,843 & $9.7(5.4-14.0)$ & $10.1(6.7-15.0)$ & 928 & $21.3(16.3-26.4)$ & $20.3(15.6-26.0)$ & -10.2 \\
\hline Management & 5,891 & $9.7(8.4-11.0)$ & $10.6(9.1-12.2)$ & 3,917 & $26.3(24.1-28.6)$ & $24.9(22.6-27.2)$ & -14.3 \\
\hline Legal & 895 & $9.8(6.2-13.5)$ & $14.0(9.8-19.6)$ & 333 & $14.6(9.2-19.9)$ & $20.6(14.4-28.6)$ & -6.6 \\
\hline Sales and related & 5,077 & $10.6(9.0-12.1)$ & $10.1(8.7-11.8)$ & 2,728 & $25.7(23.0-28.4)$ & $23.0(20.5-25.8)$ & -12.9 \\
\hline Production & 2,264 & $11.2(9.0-13.4)$ & $9.4(7.7-11.4)$ & 1,307 & $31.0(26.9-35.1)$ & $24.4(21.0-28.1)$ & -15.0 \\
\hline Farming, fishing, and forestry & 420 & $12.2(7.6-16.8)$ & $12.7(8.7-18.1)$ & 311 & $55.5(47.1-63.8)$ & $38.1(29.7-47.3)$ & -25.5 \\
\hline $\begin{array}{l}\text { Arts, design, entertainment, sports, } \\
\text { and media }\end{array}$ & 1,350 & $12.4(6.3-18.6)$ & $12.3(7.4-19.8)$ & 613 & $16.3(11.9-20.7)$ & $18.0(13.5-23.7)$ & -5.7 \\
\hline $\begin{array}{l}\text { Building and grounds cleaning } \\
\text { and maintenance }\end{array}$ & 2,027 & $12.4(9.1-15.8)$ & $11.6(8.8-15.2)$ & 973 & $28.8(23.9-33.8)$ & $25.9(21.6-30.7)$ & -14.2 \\
\hline Transportation and material moving & 2,328 & $12.4(10.0-14.8)$ & $10.6(8.7-12.9)$ & 1,426 & 33.7 (29.6-37.9) & $25.0(21.5-28.9)$ & -14.4 \\
\hline Food preparation and serving related & 1,748 & $14.7(11.4-17.9)$ & $11.2(8.7-14.2)$ & 867 & $27.0(21.9-32.1)$ & $21.0(16.8-25.9)$ & -9.8 \\
\hline Protective service & 1,188 & $15.7(11.7-19.7)$ & $12.7(9.6-16.7)$ & 531 & $34.8(26.8-42.7)$ & $25.4(18.9-33.3)$ & -12.7 \\
\hline Installation, maintenance, and repair & 1,518 & $16.2(12.9-19.5)$ & $12.8(10.3-15.8)$ & 991 & $38.4(32.9-43.8)$ & $27.0(22.7-31.9)$ & -14.2 \\
\hline Construction and extraction & 2,469 & $18.0(15.4-20.7)$ & $14.1(12.0-16.4)$ & 1,792 & $43.7(39.9-47.5)$ & $32.1(28.6-35.8)$ & -18.0 \\
\hline All occupational groups & 54,187 & $10.4(9.9-10.9)$ & - & 30,406 & $23.6(22.8-24.4)$ & - & - \\
\hline
\end{tabular}

Abbreviation: $\mathrm{Cl}=$ confidence interval.

* Weighted estimates.

† From the 2000 Standard Occupational Classification System. http://www.bls.gov/soc/.

$\S$ California, Florida, Illinois, Louisiana, Maryland, Michigan, Minnesota, Mississippi, New Jersey, New Mexico, New York, Oregon, Washington, and Wisconsin ( $\mathrm{n}=54,187$, $64 \%$ of respondents).

"Massachusetts, Montana, Nebraska, New Hampshire (no seat belt law), North Dakota, Utah, and Wyoming ( $\mathrm{n}=30,406,36 \%$ of respondents).

** Adjusted by age group, sex, race/ethnicity, education, marital status, body mass index, urban/rural county of residence, and state seat belt law type.

The current report estimates that workers in several groups with occupations for which driving is not a primary job duty (including construction and extraction; farming, fishing, and forestry; installation, maintenance, and repair; and protective service) report lower frequency of seat belt use than workers in transportation and material moving occupations. Previous research has suggested lower seat belt use rates among construction workers and occupants of commercial light vehicles (4), particularly pick-up trucks $(5,6)$, and that police officers might view seat belt use as a safety concern in high threat situations (7). However, it is possible that not enough attention has been directed toward promoting seat belt use among the 14 million workers in these broad categories because driving is not their primary job duty.

The findings in this report are subject to at least five limitations. First, seat belt use is self-reported, which, because of social desirability bias, might result in higher reported frequency of seat belt use than that reported in observational studies. Second, this analysis does not distinguish between work-related and personal driving, and there is evidence from one study that frequency of seat belt use among commercial motor vehicle drivers is higher when driving a personal vehicle than when engaged in work-related driving (4). Third, the seat belt use question says "car"; it is not known whether respondents who drive vehicles other than cars (e.g., trucks) interpreted "car" to include other vehicles. Fourth, households without telephones are excluded from BRFSS; however, this should have a minimal impact on the findings because only an estimated $2.5 \%$ of households do not have telephones. ${ }^{\dagger \dagger}$ Finally, because the overall survey response rates among the 21 states ranged from $31.1 \%$ to $59.2 \%$, nonresponse bias is possible.

Because seat belt laws are strongly associated with seat belt use $(1,8)$, states that implement new primary seat belt laws might see a substantial increase in seat belt use by all drivers, including currently employed workers; this would benefit

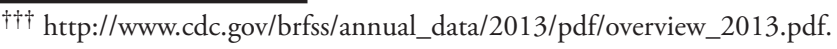




\section{Summary}

What is already known about this topic?

Although motor vehicle crashes are the leading cause of occupational fatalities, and seat belts have been shown to reduce injuries, previous reports on worker seat belt use have been narrowly focused on only a few occupations.

What is added by this report?

This is the first report on seat belt use among a broad range of occupational groups in a representative, population-based sample. For all occupational groups, the prevalence of not always using seat belts was higher in states with secondary seat belt laws (23.6\% unadjusted) than in states with primary seat belt laws (10.4\% unadjusted). After adjusting for age, sex, race/ ethnicity, education, marital status, body mass index, county urbanization, and state seat belt law type, there was substantial variability among occupational groups in self-reported seat belt use. The occupational groups with the highest adjusted prevalences included construction and extraction (14.1\%); legal (14.0\%); installation, maintenance, and repair (12.8\%); protective service (12.7\%); and farming, fishing, and forestry (12.7\%).

What are the implications for public health practice?

Employers can establish comprehensive safety programs that require consistent seat belt use at all times. States that implement primary seat belt laws might see a substantial increase in seat belt use by currently employed workers. Seat belt safety advocates could focus interventions on the occupational groups with the lowest reported seat belt use.

employers, workers, and the general public. Employers can reduce injuries among workers by implementing comprehensive safety programs that require seat belt use at all times for employees and contractors (drivers and passengers) and reinforcing this policy in training programs $(3,6,9,10)$. $\$ \$ \$$ Although many of the workers in occupations with low rates of seat belt use might be self-employed or work in small businesses that do not have comprehensive safety programs, it would still be beneficial for employers to focus on seat belt safety. Employers and seat belt safety advocates might consider developing additional interventions directed at workers in the occupations with the lowest self-reported seat belt use.

\footnotetext{
$\$ \$ \$$ CDC. Preventing work-related motor vehicle crashes. DHHS (NIOSH) publication no. 2015-111. March 2015. http://www.cdc.gov/niosh/ docs/2015-111/.
}

\section{Acknowledgments}

Jan Birdsey, Susan Burton, Stephanie Pratt, Jeff Purdin, Pam Schumacher, Aaron Sussell; 21 state BRFSS coordinators.

\footnotetext{
${ }^{1}$ Division of Surveillance, Hazard Evaluations and Field Studies, National Institute for Occupational Safety and Health, CDC; ${ }^{2}$ Division of Safety Research, Center for Motor Vehicle Safety, National Institute for Occupational Safety and Health, CDC.

Corresponding author: Winifred L. Boal, wboal@cdc.gov, 513-841-4266.
}

\section{References}

1. CDC. Vital signs: nonfatal, motor vehicle-occupant injuries (2009) and seat belt use (2008) among adults_-United States. MMWR Morb Mortal Wkly Rep 2011;59:1681-6.

2. Beck LF, Shults RA, Mack KA, Ryan GW. Associations between sociodemographics and safety belt use in states with and without primary enforcement laws. Am J Public Health 2007;97:1619-24. http://dx.doi. org/10.2105/AJPH.2006.092890

3. Chen GX, Collins JW, Sieber WK, et al. Vital signs: seat belt use among long-haul truck drivers-United States, 2010. MMWR Morb Mortal Wkly Rep 2015;64:217-21.

4. Kim K, Yamashita EY. Attitudes of commercial motor vehicle drivers towards safety belts. Accid Anal Prev 2007;39:1097-106. http://dx.doi. org/10.1016/j.aap.2007.02.007

5. Eby DW, Fordyce TA, Vivoda JM. A comparison of safety belt use between commercial and noncommercial light-vehicle occupants. Accid Anal Prev 2002;34:285-91. http://dx.doi.org/10.1016/ S0001-4575(01)00024-0

6. Retzer KD, Hill RD, Pratt SG. Motor vehicle fatalities among oil and gas extraction workers. Accid Anal Prev 2013;51:168-74. http://dx.doi. org/10.1016/j.aap.2012.11.005

7. Oron-Gilad T, Szalma JL, Stafford SC, Hancock PA. Police officers seat belt use while on duty. Transp Res, Part F Traffic Psychol Behav 2005;8:1-18. http://dx.doi.org/10.1016/j.trf.2004.10.005

8. Shults RA, Nichols JL, Dinh-Zarr TB, Sleet DA, Elder RW. Effectiveness of primary enforcement safety belt laws and enhanced enforcement of safety belt laws: a summary of the Guide to Community Preventive Services systematic reviews. J Safety Res 2004;35:189-96. http://dx.doi. org/10.1016/j.jsr.2004.03.002

9. American National Standards Institute/American Society of Safety Engineers (ANSI/ASSE). Safe practices for motor vehicle operations (ANSI/ASSE Z15.1-2012). New York, NY: American National Standards Institute; 2012.

10. Network of Employers for Traffic Safety. NETS' comprehensive guide to road safety. Vienna, VA: Network of Employers for Traffic Safety; 2014. http:// trafficsafety.org/nets-comprehensive-guide-to-road-safety-download 